\title{
Circulation of Journals.
}

The following journals are available at the Library :

Acta Psychiatrica et Neurologica.

American Journal of Mental Deficiency.

American Journal of Orthopsychiatry.

Amorican Journal of Psychiatry.

Archives of Neurology and Psychiatry.

Brain.

British Journal of Addiction.

British Journal of Medical Psychology.

L'Encéphate.

Excerpta Medica, Neurology and Psychiatry.

Howard Journal.

International Journal of Psycho-A nalysis.

Journal of Abnommal and Social Psychology.

Journal of Nervous and Mental Diseases.

Journal of Neurology, Neurosurgery and Psychiatry.

Journal of Psychology.

Mental Health.

Mental Hygiene.

Psychiatric Quarterly.

Psychological Abstracts.

Psychological Review.

Revue Neurologique.

\section{NOTICES BY THE REGISTRAR. \\ Badges.}

The Registrar regrets that owing to the difficulty of obtaining silver, nursing badges (brooch type) cannot be supplied at present. Medical Superintendents will be advised as soon as the stock has been replenished. (This notice does not apply to Mental Deficiency badges.)

\section{Bronze Medal and Prize.}

Dissertations for the Association's Bronze Medal and Price should be forwarded to reach the Registrar not later than April 30 for each year.

Divisional Prizes.

Papers certified as eligible for this competition must be forwarded to reach the Registrar not later than April 30 for each year.

\section{Gaskell Medal and Prize.}

The examination for the Gaskell Medal and Prize is held annually in May. An entrance fee of $£ 33$ s. is charged, returnable to bona-fide candidates. Entrance fees are due by March 3I.

\section{The Diploma in Psychological Medicine.}

The first examination for the Association's Diploma in Psychological Medicine will be held in November of this year and thereafter annually in May and November. The examination comprises :

Part I (a) Psychology.

(b) Anatomy and Physiology in their relation to nervous and mental diseases.

Part II (a) Psychiatry.

(b) Psychosomatic Medicine and Neurology.

Fees are eight guineas for Part I and twelve guineas for Part II, and are payable to the Registrar, R.M.P.A.

Prospective candidates should apply to the Registrar at least two months before the examination at which they wish to sit.

Full particulars may be obtained from the Registrar, R.M.P.A., I I, Chandos Street, London, W.I, on receipt of stamped, addressed envelope. (Price 3d., postage Id.) 